\title{
A Study of Collaborative Learning among Malaysian Undergraduates
}

\author{
Anis Maesin (Corresponding author) \\ Academy of Language Studies, Universiti Teknologi MARA \\ 02600 Arau, Perlis, Malaysia \\ Tel: 4-987-5310 E-mail: anismaesin@perlis.edu.my \\ Mahani Mansor \\ Academy of Language Studies, Universiti Teknologi MARA \\ 02600 Arau, Perlis, Malaysia \\ Tel: 4-987-5310Ｅ-mail: mahani@perlis.uitm.edu.my \\ Latisha Asmaak Shafie \\ Academy of Language Studies, Universiti Teknologi MARA \\ 02600 Arau, Perlis, Malaysia \\ Tel: 4-987-5310Ｅ-mail: ciklatisha@perlis.uitm.edu.my \\ Surina Nayan \\ Academy of Language Studies, Universiti Teknologi MARA \\ 02600 Arau, Perlis, Malaysia \\ Tel: 4-987-5310Ｅ-mail: surinana@perlis.uitm.edu.my
}

\begin{abstract}
This study was to investigate Malaysian undergraduates' preference for collaborative learning activities that were carried out during English lessons. Gender, location and programme were studied in order to determine their influence on the undergraduates' preference. The study was carried out on four groups comprised of science and social science undergraduates. The respondents were asked to respond to a set questionnaire that was adapted from Cantwell \& Andrews' Feelings Toward Group Work Questionnaire (1998) \& Reid's Perceptual Learning Questionnaire (1987). The results indicated that all the undergraduates preferred to participate in collaborative learning activities during their English lessons.
\end{abstract}

Keywords: Collaborative learning, Malaysian undergraduates

\section{Introduction}

Collaborative learning is defined as classroom learning techniques which require students to work together in groups or pairs in learning tasks (Colbeck et al., 2000). Students from different levels work together for a common goal as they are responsible for their own learning and for others in their group. Johnson, Johnson, and Smith, (1991) indicate that collaborative learning requires elements of positive interdependence, individual accountability, face-to-face promotive interaction, appropriate use of collaborative skills and group processing. Students are given opportunities to learn by inquiry under the guidance of a teacher and at the same time developing communicative skills, leadership skills and interpersonal skills (Bean, 2001). Learners will have more opportunities to interact with peers, present and defend ideas, exchange diverse beliefs, question other conceptual frameworks and be actively engaged in collaborative learning setting (Srinivas, n.d.).

In second language learning, students find difficulties to utilize the language skills outside of language classrooms as 
there are fewer opportunities to do so due to poor language environments. Thus, teachers need to ensure that students use English in discussing and communicating with each other in the classroom. Yet students find it difficult to utilize the language due to the class size, learning style preferences and teachers' approaches to teaching. On the other hand, teachers are concerned about the low proficiency level of the students and the large class size that they need to deal with as a typical class could reach up to 55 students.

This paper investigates how students responded to collaborative learning activities. It aims at finding how useful students consider collaborative learning activities in learning English by discussing and solving tasks classmates in groups. 162 students at semester two were chosen to respond to questionnaires in English regarding the usage of collaborative learning activities in their language classes. Questionnaires were distributed to get the information needed to see if students enjoyed collaborative learning activities with peers. It is expected that students find collaborative learning activities useful toward their formal curriculum. The significance of the study is to provide teachers much informed decisions in their selection of English classroom activities. The research was carried out to determine whether the second semester Universiti Teknologi MARA Perlis students prefer collaborative learning during English lessons and to determine whether there was a significant difference in students' preference for collaborative learning by gender.

\section{Literature Review}

Collaborative learning differs from traditional teaching approaches because students work together rather than compete with each other individually. It can take place any time students work together like when they help each other with homework or when students work together in the same place on a structured project in a small group. Collaborative learning helps students become actively and constructively involved in content, to take ownership of their own learning and to resolve group conflicts and improve teamwork skills.

In language learning, Harmer (1991) proposes that collaborative learning provides maximum opportunities for students to interact and cooperate with one another as they work towards a common goal by using four language skills such as speaking, listening, reading and writing. Regardless of their different language proficiencies and personalities, students work better in groups as Delucchi (2006) reports that students preferred collaborative learning on language activities as these activities enabled them to exchange more opinions and ideas. This was because they felt less anxious, so they could perform better than when they worked alone. This situation is explained by Krashen (1988) as learning English in less anxiety situations that result in effective learning. Regarding the number of members for collaborative learning, Dillenbourg \& Schneider (n.d.) observe that small groups seem to function better than large groups in which some members tend to be 'asleep' or excluded from interesting interactions. Davis \& Bass (1993) suggest that a group should have a number of no more than six students. According to them, a group larger than six has several weaknesses. It is too easy for students to become passive observers rather than active participants, students may not get the opportunity to speak fluently since there are so many people, students' sense of community and responsibility may be less intense in large groups.

Students' present learning preferences are heavily influenced by their past learning experiences. Anis Maesin (2006) in her study on a group of UiTM students finds that students regardless from urban or rural areas equally preferred collaborative learning. Reid (1987) conducted a study on six learning style preferences on graduates of ten groups of students from different language backgrounds; Malay, Korean, Chinese, Spanish, Japanese and English speakers. In the study, Reid finds that 113 Malay students preferred group learning style as their favorite learning style meanwhile the English speakers chose group learning style as the least favourite learning style. The finding indicates previous educational experiences influence students' present learning style preferences. Web (1982) explains the nature of Asian students as being submissive, anxious and talk less in classrooms so through collaborative learning, Asian students are able to learn better and more effectively.

In a class setting whereby it consists of many races as such in many higher learning institutions in Malaysia, students are able to learn to work will all types of people from different backgrounds. Therefore, they will find many opportunities to reflect upon and reply to the diverse responses their friends bring to the questions raised. Small groups also allow students to add their perspectives to an issue based on their cultural differences. This exchange will definitely help students to better understand other cultures and points of view. In addition, Norhayati et. al (2005), in their research on on-line collaborative learning (used the collaboration tool to discuss and complete the project given) find that on-line collaboration-learning group scored higher than the traditional collaboration-learning group (face to face discussion on the project).

Participating in collaborative learning allows students to be critical in their thinking. Critical thinking among undergraduates is dictated by learning environments and the teachers' approaches to teaching. Gokhale (1995) finds that students who participated in collaborative learning performed significantly better on critical thinking than students who studied individually. According to Johnston et al (2000), collaborative learning through problem solving encourages critical thinking as it allows knowledge retention as students apply knowledge in other contexts. At the same time, it enhances interpersonal skills. It is imperative for teachers to know their students' learning style preferences as Yazici 
(2005) indicates that by knowing students' preferences for collaborative learning, teachers can take appropriate measures that enhance learning of English. Raja Maznah (2004) in her study on web-based collaborative learning activities finds out that the students involved in the research reported that they were able to expand and stretch their creativity to think of innovative ideas.

Gokhale (1995) in her investigation on the effectiveness of individual learning versus collaborative learning in enhancing drill-and-practice skills and critical-thinking skills finds that collaborative learning fosters the development of critical thinking through discussion, clarification of ideas and evaluation of others' ideas. If the purpose of teaching and learning is to enhance critical-thinking and problem-solving skills, then collaborative learning is more beneficial than individual learning. However, if the purpose of teaching and learning is to get factual knowledge, then both methods individual learning and collaborative learning should be adopted. To sum up, collaborative learning activities do contribute well in students' ability to work together in groups that further enhance their creativity and thinking skills.

M.Z. Kamsah \& R. Talib (2003) discover that the lecturers and the final year engineering students at Faculty of Chemical and Natural Resources Engineering (FKKKSA) at Universiti Teknologi Malaysia Skudai agreed on the importance of group work activities in classrooms. Both groups also agreed on the effectiveness of group work on cognitive skills. They agreed on the improvement of the understanding of materials through discussions, solving assignments and increasing memory retention and thinking skills. Brown (2008) in her research on students' perceptions of collaborative learning (CL) in University of Botswana discovers that most students claimed to have derived academic benefits such as better comprehension and improved performance and acquired generic skills-enhanced communication and problem-solving skills. She also finds that most students agreed that CL practices should be encouraged and continued. They also found that CL is enjoyable and they can make new friends through it.

\subsection{Existing patterns of individual learning}

There is a conventional perception towards Asian learners in general regarding their approach to learning. Asian students are assumed to bring with them learning experience that favour 'rote, reproductive, surface, teacher-centred and dependent approaches to learning' (Ninnes, Aitchison, \& Kalos, 1999; Ballard \& Clanchy, 1997; Devos, 2003; Gribble \& Ziguras, 2003 as cited in Ling, et. al., 2005). Wong (2004) in a study of Asian international undergraduates in a university in Australia reveals Malaysian undergraduates experienced teacher-centered learning, rote memorizing and 'spoon-feeding' during high schools in Malaysia. The undergraduates were lost at the beginning of the semester at the university as a result of different learning and teaching styles practiced by the university. However after two months, these undergraduates were able to adapt to new learning styles adopted by the university. The undergraduates confessed that they preferred learner-centered learning styles as they were able to have more freedom and in control of their learning.

Mohd Hanif and Norsafinas (2006) in their study of 1193 undergraduates of three universities in Malaysia state that most undergraduate programs are course works which comprise of assignments, groups projects, presentations and class discussions .The course works require undergraduates to work in groups and collaborate with each other. This requirement results in undergraduates of adopting collective learning styles rather than individualistic learning style. In a research done by Othman, Wong, Shah Christirani and Nabilah (2009) on 'Uncovering Malaysian students' motivation to learning Science", they find that the majority of the respondents think that peers not only helped to clarify concepts that they were uncertain, but also these peers have become the source of information. Besides, these respondents also saw their friends as motivators where they promoted healthy competition in ensuring who would perform the best among them. Based on their research on strategies for facilitating the participation of Asian and other students in Problem-Based Learning, Remedios, Clarke and Hawthorne (n.d.) find that it is common for Asian students to limit their verbal contribution due to their concern over the quality and accuracy of their information. Besides, these Asian students found it hard to enter discussions since they had the belief that local students were better at presenting information.

\section{Methodology}

\subsection{Research subjects}

The purpose of the study is to find out the preference for collaborative learning activities among Part Two Universiti Teknologi MARA (UiTM) Perlis students. The students comprise of the Malay students who have had about two semesters of English language class in UiTM Perlis. The students' classes consist of about 30 to 35 students of mixed gender and posess various levels of English proficiency. They have completed a semester of English course that was designed to raise students' level of basic English proficiency. The students were selected as samples for the study because they have had experienced participating in group activities in English lessons during the previous semester of study. The students are of between 19 to 20 years of age. This group of students reflects a typical classroom in Malaysia which comprises diverse socio-economic and sociopolitical variables, namely urban-rural students, socioeconomic status, reasons and motivation to learn English, and attitudes toward learning English (Mukundan \& Seng, 2002). They 
are also most likely affected by these factors. One aspect that is exceptional is that they are all of the same race, Malay. Therefore, it is assumed that the students' cultural inclination would be very similar. However, for the purpose of the study, only two factors are taken into account; gender and programme enrolled in UiTM Perlis. These factors were investigated in relation to students' preference for collaborative learning. A total of 162 students were selected to participate in the study. 93 of the students were from the science programme and 51 from the social science programme. The respondents were 87 male students and 72 female students.

\subsection{Research instrument}

The survey method was used in the procedure of data collection for this study. The respondents were asked to respond to a set of questionnaire that was adapted from Cantwell \& Andrews' Feeling Toward Group Work Questionnaire (1998) and Reid's Perceptual Learning Questionnaire (1987). The respondents' responses are ranked on a Likert scale of (1) to (5). (5) in the Likert scale indicates "strongly agree", (4) "agree", (3) "not sure", (2) "disagree" and (1) "strongly disagree". The Statistical Package for the Social Science 13.0 (SPSS) for Windows was used for the analysis of data collected using the questionnaire. Descriptive statistics and the independent samples t-test were used to analyse the students' responses.

\section{Results and Discussion}

The level of students' preference toward collaborative learning has been put into three categories; high preference, medium preference and low preference. Table 1 illustrates these categories of scores. (Table 1)

The overall result of students' preference for collaborative learning is illustrated in Table 2. It was found that none of the 162 respondents had a low level of preference for collaborative learning during English lessons. 12 respondents (7.4\%) had an average level of preference and 150 respondents $(92.6 \%)$ had a high level of preference. This strongly indicates that all the respondents preferred collaborative learning during English lessons. In fact, more than three quarter of the respondents had a high level of preference compared to the average level of preference. This means that there were overwhelmingly more respondents who had a high level of preference than those who had an average level. In short, the findings show that the whole sample preferred to participate in collaborative learning activities during English lessons. (Table 2)

The level of preference for collaborative learning based on the respondents' gender is illustrated in Table 3. It shows that, for the male respondents, none had a low level of preference, 6 respondents $(6.9 \%)$ had an average level of preference, and 81 respondents $(93.1 \%)$ had a high level of preference. As for the female respondents, none had a low level of preference, 4 (5.6\%) had an average level of preference, and 68 (94.4\%) had a high level of preference. In other words, this means that not a single male or female respondent had a low level of preference for collaborative learning during English lessons. Therefore, all the respondents had either an average or a high level of preference for collaborative learning. For both the male and female respondents, the percentage for those who had a high level of preference is strikingly higher than those with an average level of preference. This shows that both the male and female respondents generally preferred collaborative learning. In fact, there were more of them who had a high level of preference than an average level of preference. (Table 3)

The findings of the level of preference according to the programme that they enrolled in are illustrated in Table 4. It was found that none of the science programme respondents had a low level of preference for collaborative learning, 9 respondents (9.7\%) had an average level of preference, and $84(90.3 \%)$ had a high level of preference. As for those respondents who enrolled in the social science programme, none had a low level of preference for collaborative learning, only 1 respondent (2\%) had an average level of preference, and the rest, 50 respondents $(98 \%)$ had a high level of preference. This clearly shows that almost all the respondents from both science and social science programmes preferred collaborative learning during their English lessons. (Table 4)

An independent samples t-test was carried out on collaborative learning preference and gender showed that there was no significant difference in the students' preference towards collaborative learning by gender $[t(159)=0.336, p>.05]$. In other words, the students' preference for collaborative learning during English lessons was equally shared by the male as well as the female students. Even so, the means for the male respondents $(\mathrm{M}=80.28, \mathrm{SD}=9.27)$ was slightly higher than the females' $(\mathrm{M}=79.85, \mathrm{SD}=6.80)$. This indicated that the male students had a slightly more preference toward collaborative learning compared to the female students.

Another independent samples t-test that was carried out on collaborative learning preference and programme showed that there was a significant difference in the students preference for collaborative learning when it comes to the different programmes $[\mathrm{t}(159)=-3.476, \mathrm{p}<0.5]$. In short, the students' preference for collaborative learning during English lessons varies according to the two programmes that were selected for this study. The means for the two groups showed that the social science respondents' $(M=83.29, \mathrm{SD}=8.30)$ was higher than the science students' $(\mathrm{M}=78.62, \mathrm{SD}=7.37)$. It can be concluded that the social science students preferred collaborative learning more than the science students. 


\section{Conclusions}

The transitions of Malaysians students from schools to higher institutions of learning may be difficult because of the existing patterns of learning that emphasize more on surface learning, rote memorization and dependent learning rather than deep learning that is more exploratory and analytical. According to Noorizah Mohd. Noor (2006), a few studies conducted by Malaysian educationists found that Malaysian students were not independent enough (Farida, 1995) and they were expected to be "spoon-fed" with information and notes (Sarjit \& Salasiah, 1996). This approach to learning caused failure in studies at tertiary level due to lack of effective study skills, reading, writing time and stress management skills (Ellis, 1996 as cited in Noorizah Mohd. Noor, 2006). The biggest problem that has been the outcome of individual learning amongst Malaysian students in general is the inability of Malaysian graduates to communicate effectively, in English in particular. This problem has been repeatedly highlighted in some of the national newspapers. Even though students in Malaysia have gone through years of learning English, it appears that it has been somewhat ineffective. For instance, many students are found not confident and in fact, afraid to use English in public (Fauzi, 2005). It was also found that Malaysian university students are generally weak in communication as they are unable to communicate effectively and produce sound arguments due to their inability to adapt to team learning that is largely used in universities (Muhammad Hasan, 2001).

This study has found that almost all of the students preferred collaborative learning activities. As educators, our utmost concern is to enhance our students' learning. Therefore, obtaining information about our students' learning preferences could be one of the ways in achieving this. We should be aware of their needs as well as what they want to experience in their English lessons. With such information, language instructors will be able to prepare and select activities that would cater for their students' learning preferences. This will result in achieving better academic performance (Eslami-Rasekh \& Valizadeh, 2004) as well as other positive learning outcomes (Cruickshank, Bainer \& Metcalf, 1995).

A study such as this will provide language instructors with a valuable insight of their own group of learners' learning preference. There are a number of studies which have been carried out by foreigners on foreign learners. Even when the studies were carried out on Malaysian students, the findings might not necessarily reflect the preference of the group of students that one is teaching. Thus, this shows that language instructors need to find out for themselves in order to know the learning preference that is specific to their own group of students in its local setting.

To fulfill the students' interest to work collaboratively, language instructors can select or prepare language activities that will enable students to work collaboratively during English lessons. They can plan their lessons according to the students' preference by incorporating collaborative language activities such as group projects and small group discussions into their lessons to practise all four skills of speaking, listening, reading and writing. This will help them to feel at ease in using English. In other words, they will be able to learn, practise and use English in a comfortable atmosphere as a result from working together in enjoyable and meaningful collaborative activities.

\section{References}

Anis Maesin. (2006). Students' Preference for Collaborative Learning Activities during English Lessons. (Project Paper for Master of Science, University Utara Malaysia, 2006)

Bean, John C. (2001). Engaging Ideas: The Professor's Guide to Integrating Writing, Critical Thinking, and Active Learning in the Classroom. San Francisco: Jossey-Bass Publishers.

Brown, F. A. (2008). Collaborative learning in the EAP classroom: Students' perception. [Online] Available: www.esp-world.info/Articles_17/issue_17.htm

Colbeck, C.L., Campbell,S.E., \& Bjorklund, S.A. (2000). Grouping in the Dark: What College Students Learn from Group Projects. The Journal of Higher Education, 71(1), 60-83

Cruickshank, D.R., Bainer, D. \& Metcalf, K. (1995). The Act of Teaching. U.S. McGraw-Hill, Inc.

Davis, B.G. \& Bass, D. (1993). Collaborative learning: group work and study teams. [Online] Available: http://teaching.berkeley.edu/bgd/collaborative.html (January 28, 2009)

Delucchi, M. (Spring 2006). The efficacy of collaborative learning groups in an undergraduate statistics course. College Teaching, 54(2), 244-248.

Dillenbourg, P. \& Schneider, D. (n.d.). The conditions for effective collaborative learning. [Online] Available: http://gdrc.org/kmgmt/c-learn/conditions.html (January 18, 2009)

Eslami-Rasekh, Z. \& Valizadeh, K. (2004). Classroom activities viewed from different perspectives: learners' voice and teachers' voice. [Online] Available:http://writingBerkeley.edu/TESL-EJ/ej31/a2.html (July 6, 2005)

Fauzi Halim (2005, December 12). Ubah Pendekatan Mengajar Bahasa. Utusan Malaysia. Retrieved 16 September 2005, from http://www.utusanmalaysia.com.my

Gokhale, A. A. (1995). Collaborative Learning enhances critical thinking. [Online] Available: 
http://scholar.lib.vt.edu/ejournals/JTE/jte-v7n1/gokhale.jte-v7n1.html (October 10, 2008)

Harmer, J. (1991). The Practice of English Language Teaching (New ed.). UK: Longman Group. UK Limited.

How do cooperative and collaborative learning differ from the traditional approach? [Online] Available: http://www.thirteen.org/edonline/concept2class/coopcollab/index_sub1.html (January 28, 2009)

Johnson, D.W., R.T. Johnson \& K.A. Smith. (1991). Cooperative Learning: Increasing College Faculty Instructional Productivity, ASHE-ERIC Higher Education Report No. 4. George Washington University.

Johnston, C.G., James, R. H., Lye, J. N. \& McDonald, I. M. (2000). An Evaluation of Collaborative Problem Solving for Learning Economics. Journal of Economic Education, 31(1), 13-29

Krashen, S. (1998). Second Language Acquisition and Second Language Learning. UK: Prentice Hall International (UK) Ltd.

Ling, P. et. al. (2005). Approaches to study; A Comparison of Malaysian and Australian students. [Online] Available: http://conference.herdsa.org.au/2005/pdf/refereed/paper_174.pdf

M.Z.Kamsah \& R. Talib. (2003). Assessing group work activities in Engineering Education. [Online] Available: http://www.ctl.utm.my/research/pdf/rtl05.pdf (March 12, 2009)

Mohd. Haniff Jedin \& Norsafinas Md. Saad. (2006). A preliminary study on gender and learning style in Malaysian higher learning institutions: Evidence from a cultural perspective. The Higher Education Research and Development Society of Australasia Conference 2006. [Online] Available: herdsa.org.au/2006/ http://www.herdsa.org.au/wp-content/uploads/conference/2006/Haniff.pdf (May 5, 2009)

Muhammad Hasan Abdul Rahman. (2001, March 5). Cabaran pelajar bergelar mahasiswa. Utusan Malaysia. Retrieved 16 September 2005, from http://www.utusanmalaysia.com.my

Muhammad Kamarul Kabilan Abdullah. (1996 \& 1998). In Mukundan, J. \& T. C. Seng. (Eds.), Trends in English Language Teaching. Universiti Putra Malaysia Press. pp.45-53

Norhayati Abd. Mukti, et. al. (2005). Hybrid learning and online collaboration enhance students' performance. [Online] Available: http://mysis.fsktm.um.edu.my/1132 (January 28, 2009)

Othman Talib, Wong Su Lan, Shah Christirani Azhar, Nabillah Abdullah. (2009). Uncovering Malaysian students' motivation to learning Science. European Journal of Social Sciences, 8(2), 266-276

Raja Maznah Raja Hussain. (2004). A collaborative experience of evaluating a web-based learning tool. Malaysian Online Journal of Instructional Technology (MOJIT). [Online] Available: http://pppj.usm.my/mojit/articles/pdf/1204/A\%20Collaborative\%20Experience\%20\%20Evaluating.pdf (January 28, 2009)

Reid, J. (1987). The learning style preferences of ESL students. TESOL Quarterly, 21(1), 87-111

Remedious, L., Clarke, D. \& Hawthorne, L. (n.d.). Strategies for facilitating the participation of Asian and other students in Problem-Based Learning. [Online] Available: www.med-ed-online.org/resoursec/PBL_strategies.doc(January 28, 2009)

Sarjit Kaur \& Salasiah Che Lah. (1996). Language learning strategies of Malay university students: an exploratory study. Journal of Humanities. 6, 98-118

Srinivas, H. (n.d.). What is collaborative learning? National Institute of Science Education. [Online] Available: http://www.gdrc.org/kmgmt/c-learn/what-is-cl.htm (January 28, 2009)

Web, N. M. (1982). Student interaction and learning in small groups. A Review of Educational Research, 52, 421-425

Wong, J. K. (2004). Are the Learning Styles of Asian International Students Culturally or Contextually Based. International Education Journal.

http://ehlt.flinders.edu.au/education/iej/articles/v4n4/wong/paper.pdf (May 5, 2009)

Yazici, H. J. (April 2005). A study of collaborative learning style and team learning performance. Education and Training Journal, 47(3), 216-229 
Table 1. Levels of Collaborative Learning Preference

$\begin{array}{cl}\text { Total Scores } & \text { Level of Preference } \\ 0-29 & \text { Low Preference } \\ 30-69 & \text { Average Preference } \\ 70-100 & \text { High Preference }\end{array}$

Table 2. Overall Students' Preference for Collaborative Learning

\begin{tabular}{lcc} 
Level of Preference & Frequency & Percentage \\
Low & 0 & 0 \\
Average & 12 & $7.4 \%$ \\
High & 150 & $92.6 \%$ \\
\hline Total & 162 & $100 \%$ \\
\hline
\end{tabular}

Table 3. Students' Preference Level According to Gender

\begin{tabular}{|l|c|c|c|c|}
\hline & \multicolumn{2}{|c|}{ MALE } & \multicolumn{2}{c|}{ FEMALE } \\
\hline & Number & Percentage (\%) & Number & Percentage (\%) \\
\hline High Preference & 81 & 93.1 & 68 & 5.4 \\
\hline Average Preference & 6 & 6.9 & 4 & 0 \\
\hline Low Preference & 0 & 0 & 72 & 100 \\
\hline TOTAL & 87 & 100 & & 0 \\
\hline
\end{tabular}

Table 4. Students' Preference Level According to Programme

\begin{tabular}{|l|c|c|c|c|}
\hline & \multicolumn{2}{|c|}{ SCIENCE } & \multicolumn{2}{c|}{ SOCIAL SCIENCE } \\
\hline & Number & Percentage (\%) & Number & Percentage $(\%)$ \\
\hline High Preference & 84 & 90.3 & 50 & 98 \\
\hline Average Preference & 9 & 9.7 & 1 & 2 \\
\hline Low Preference & 0 & 0 & 51 & 0 \\
\hline TOTAL & 93 & 100 & 5100 \\
\hline
\end{tabular}

